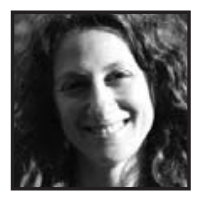

\title{
Through the Gates of Loving Inquiry: Discovering a Poetics of Relationship
}

\author{
Ahava Shira
}

\section{ABSTRACT}

I am a poet, arts-based researcher and healthy relationships educator. After many years of teaching about healthy relationships in the classroom, and writing poetry about my relationships with people, I moved to Butterstone Farm and discovered a new place of learning. Through the Gates of Loving Inquiry ${ }^{1}$ develops the conversation on how we may engage in loving relationships within and beyond the scope of our human relationships, expanding this pedagogical practice from the walls of schools and universities out toward our experience with nature.

Once in h[er] life a [wo]man... ought to give h[er]self up to a particular landscape in h[er] experience, to look at it from as many angles as [she] can, to dwell upon it. [S] he ought to imagine that [s] he touches it with [her] hands at every season and listen to the sounds that are made upon it. [S] he ought to imagine the creatures there and all the faintest motions of the wind. [S] he ought to recollect the glare of noon and all the colours of the dawn and dusk.

(Momaday, 1993, p. 83) 


\section{Preparing to Enter}

am a poet, arts-based researcher and healthy relationships educator. For many years I have been teaching myself and others to love, to move through the barriers that interfere with opening our hearts to each other. As a healthy relationships educator I have facilitated workshops with middle and high school youth for ten years, engaging them in activities and

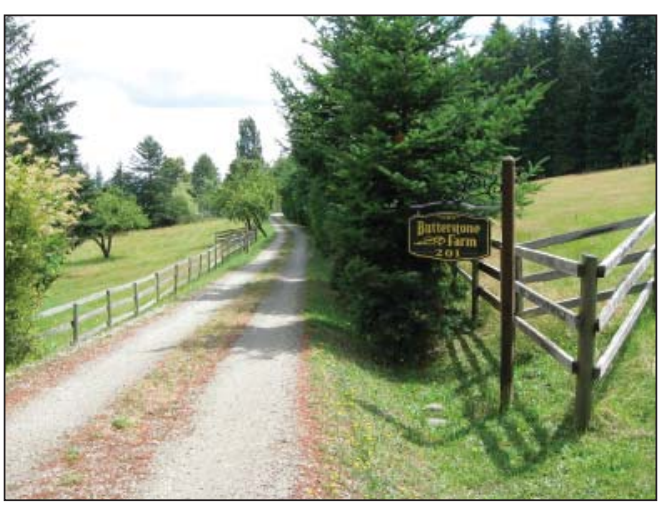

Fig. 1: Entranced conversations in order to support them in making the shift from harassment to respect, aggression to compassion.

I teach this because this is what I have struggled to learn and unlearn. Before I became a healthy relationships educator I was passionately engaged in writingboth journaling and poetry-and in performance. My personal experience as a teenager and young adult with unhealthy familial and intimate relationships was, in large part, what led me to the page. Meditation teacher Sylvia Boorstein (2002) offers:

It is our own pain, and our own desire to be free of it, that alerts us to the suffering of the world. It is our personal discovery that pain can be acknowledged, even held lovingly, that enables us to look at the pain around us unflinchingly and feel compassion being born in us. We need to start with ourselves. (p. 143)

In my book of poetry, Womb: Weaving of My Being (1998), I wrote about my experience of violence and the post-traumatic symptoms I struggled with as a result. Writing poetry enabled me to explore the complex feelings I carried from the abuse, to understand its roots in systems of gender and cultural oppression, and to envision healthier models of relationship for myself and others.

When I returned to school to pursue a master's degree, my supervisor Antoinette Oberg encouraged me to write poetry about my experience as a healthy relationships educator. As social justice educator William Ayers (2004) suggests: "Working on autobiographical texts can be a way of making values, beliefs, and 
choices accessible to teachers and prospective teachers alike. These texts-complex, idiosyncratic, alive, and changing-provide the kind of detail from which one can interpret practice" (p. 105).

These research poems developed into my final master's project, Lines of Flight: Notes on Becoming, in which I wrote about the joy and the challenge of interacting with the diverse beliefs and identities of my students and colleagues; the despair I felt from teaching within a socio-cultural context that promotes violence as a form of entertainment and conflict resolution; and the vulnerable recognition that within me lay those same impulses toward violence that I encountered in the classroom and in the world. As Buddhist teacher Pema Chodron (1994) shares:

Therefore the exchange-putting ourselves in someone else's shoesdoesn't come from theory, in which you try to imagine what someone else is feeling. It comes from becoming so familiar and so openhearted and so honest about who you are and what you do that you begin to understand humanness altogether and you can speak appropriately to the situation. (pp. 102-103)

As a PhD student I continued to engage in a practice of critical self-awareness through writing, expanding the context to include my relationships with friends and community members as well as with strangers I sat beside on the ferry or encountered on the bus. Further exposed to the arts-based practices of narrative, poetic and performative inquiry, I was also keenly influenced by the writings of feminist post-structuralist and writing process theorists who offered a new perspective with regard to theories of subjectivity, identity and how we are shaped and reshaped through language.

Then, in the fall of 2007 , at the end of a course on the arts-based research practice of Living Inquiry with Karen Meyer, I realized that all of the field notes I had written during the course demonstrated a creative and contemplative practice of shifting my experience in relationship from violence to love. Recognizing this, I shifted the "i" in Living to "o" and identified my research practice as Loving Inquiry.

At the same time that I declared my research practice Loving Inquiry, my partner and I moved-together with another couple-to Butterstone Farm. After many years of teaching about healthy relationships in the classroom, and writing poetry and essays about my experience of relationships with people (Shira, 1998, 2005, 2007, 2008, 2009), Butterstone Farm became a new place of learning, and a new environment in which to learn. 


\title{
Gates of the Heart
}

Whoever knows the gathering together into the most intimate only through suffering, does not know the illuminating grace of love.

(Irigaray, 2002, pp. 172-173)

\begin{abstract}
Butterstone Farm is a magical place: 23 acres of valley and forest, pastures and hayfields, ponds and creeks, gardens and orchards. As I walk through the farm, I am surrounded in every direction by fences. Arranged around the perimeter of the forests, gardens and pastures, these fences protect the gardens and orchards from the appetites, and deceptively far reach, of the

Fig. 2: Glow white-tailed deer that wildly inhabit the island. Each fence has its own particular, handcrafted gate.
\end{abstract}

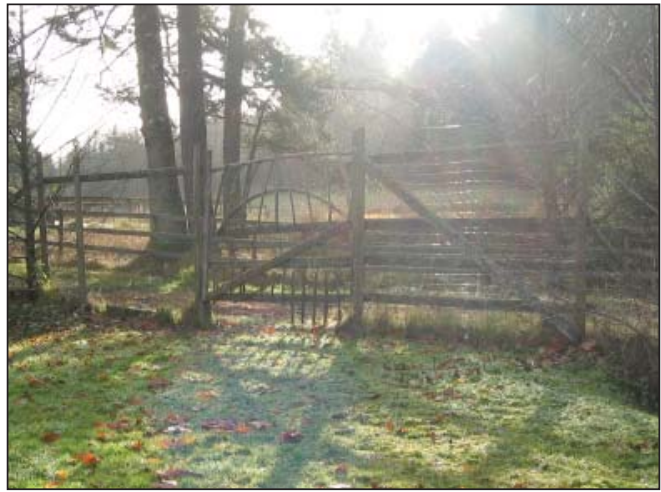

Many artists (Hirshfield, 1997; Lauterbach, 2005; Whyte, 1997), educators (Fels \& Meyer, in press; Meyer, 2006), and spiritual teachers (Arrien, 2005; Loori, 1992; Merton, 2008; Shibayama, 2000; Yamada, 2004) have used gates as a symbol and metaphor for creative, pedagogical and spiritual learning. Zen master and teacher John Daido Loori (1992) developed a path of training for monks called the Eight Gates of Zen, using gates as a symbol for entering into exploration of the nature of the self.

As I practice Loving Inquiry on the farm, I observe a similarity between my experience of opening and walking through the gates and my experience of opening and entering into relationship. Both require me to pause and to listen to what is happening inside myself as well as outside. Both need me to practice letting go of anything that is keeping me from being present-whether it is an internal belief or emotion, in the case of relationship with another, or an external barrier such as too much snow or ice in the case of the gate. Both demand my sensual, embodied awareness, and invite certain contemplative, spiritual qualities of attention. 
Walking through the gates on the farm becomes a journey of encounter, marked with a tone of sacred possibility. Attending to the ongoing sensual, visual experience of opening and closing the gates, I attend to the relationship between self and other. Each moment I practice Loving Inquiry, I walk through a gate. Sounds, smells, visual cues, sensations as well as images, metaphors and linguistic resonances all become openings into relationship.

\section{Appetite}

1.

I was house-sitting

for my farm-mate when yesterday I lost one of her cats

neglected to assure both indoor cats were present and accounted for

forgot to wonder why the cat bowl filled with crunchies went untouched

why I saw only one cat most evenings
2.

This morning Thomas

our outdoor cat perches on the roof above the barn

he usually gets his pets, and food next door, where one of the indoor cats is missing

but last night he rubbed his fur along the sliding loft doors

caress after caress

we left the doors open, invited him in his front right paw raised like a hand to be kissed he kneaded the front step like a blanket

hesitated 
3.

I scoop him up in my arms

like a bundle of kindling

he warms my mangy heart

with his soft purr

Language as a bodily phenomenon accrues to all expressive bodies, not just to the human. Our own speaking, then, does not set us outside of the animate landscape but...inscribes us more fully in its chattering, whispering, soundful depths.

(Abram, 1996, p. 80)

\section{Listening to Leaves}

1.

Walk outside

to the yard

now layered

with hundreds of

fallen leaves

startled hues of mustard

brick, coral, carrot, banana

each tree, bush, leafy plant

displays their own

distinctive shades of fall 
2.

In the museum of

modern art

in New York City

sit on a bench before

the Monet triptych

stare across at

the two Bonnards

to you they are more

alive, soulful

regardless

you are not a spectator

you are being painted

the artist strokes your

hair with a thick brush

dabs a swath of copper

for the leaf that just fell

on your lap where the cat

once lay, out of the picture now

leaves have taken his place

the painter prefers them anyways

she has had enough of cats

she wants leaves in your lap

where your hands are resting 


\section{Touching Wood}

Here, the act of knowing is an act of love, the act of entering and embracing the reality of the other, of allowing the other to enter and embrace our own.

(Palmer, 1983, p. 8)

Loving Inquiry is premised on the understanding that we are all engaged in relationships, and that-because of our connectedness and interdependence as human, and more-than-human beings-it is our ethical responsibility to engage in those relationships in a loving way.

In The Way of Love, feminist philosopher and writer Luce

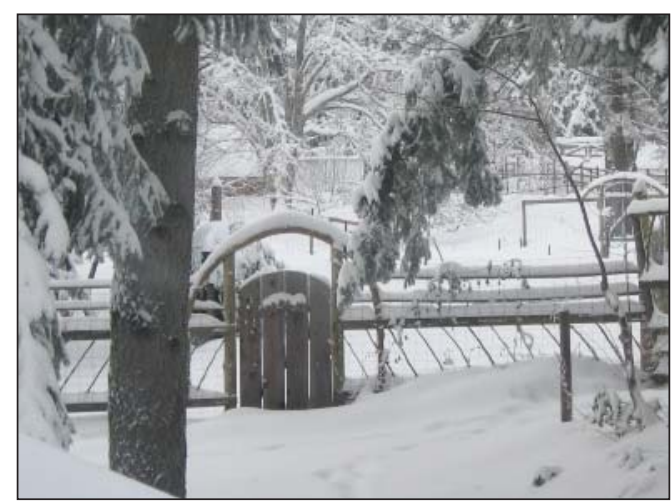

Fig. 3: Fallen Irigaray (2002) says, "Silencing what we already know is often more useful in order to let the other appear" (p. 165). In order to enter and embrace the reality of another, I have to let go of my ideas of who that other is, and/or who I want them to be. Irigaray suggests we find "gestures or words" that "touch the other in his, or her alterity" (p. 151).

Through my practice of Loving Inquiry I search for those gestures or words that touch the other in their alterity, to approach the other in what Irigaray refers to as a "poetic way of dwelling" (p. 152). Ecologist Stephan Harding (2006) offers a similar understanding with regard to our relations with the natural world:

We need to allow ourselves to be open to the subjective agency at the heart of every 'thing' in the world so that we can speak and act appropriately in their presence and on their behalf. We must keep alive and nurture a sense of 'otherness' of whatever phenomenon we might be considering, allowing a strange kind of intimacy to develop in which the urge to control is replaced by a quickening awe at the astonishing intelligence that lies at the heart of all things. (p. 37) 


\section{Bird in the Palm}

This morning as I cleaned spider webs from the corners of the window, smoothed away little cocoons with a dry cloth, I heard a bang on the glass. Another little bird hit. Quick step into boots then outside onto wet cedar deck, climb over lattice to reach the shivering body.

My palms curve around grey and white stripes. Soft down falls on the deck. I wipe a fleck from its face, caress its head, eyes open and close through a veneer of gossamer. Underneath a swatch of yellow feathers. I don't know what kind it is.

I quiet my mind, listen for other birds, wonder if it hears them too as it clutches my palm with its small black talons. I attempt bird sounds to comfort it, fail miserably.

It's only stunned, flies away before I slide the loft door open. It lands on a branch in the big leaf maple and from a distance it looks like any of the birds that perch there.

Poets make things, but they don't make poetry; poetry is present to begin with; it is there, and poets answer it if they can. The poem is the trace of the poet's joining in knowing.

(Bringhurst, 1995, pp. 53-54)

\section{Little Deer}

As I walk out to the back of the farm, my rubber boots sink into fresh tracks. The gardener told me where to look. I stop within 500 feet, let the ravens flee.

I don't mean to spoil their dinner, just want to have a closer look.

I see its ribs all bloodied the insides of its stomach brown and gelatin-like. I'm not sure what I am looking at. I step back, tell myself it is okay this is a part of life, what the body is-blood and feces and guts and ribs and we just don't see it.

Then I am able to step closer again. 
Ravens squawk in surrounding trees. Eager to get back to their dinner?

I pray for this little deer, wish it peace. It might have been the one that found its way through our fence into the garden, where it ate up the rest of the raspberries.

It escaped us. Death never does.

Through poetry I seek to enter into relationship with an openness and intimacy that keeps alive a sense of "otherness," which requires a willingness to listen, to watch, and to notice. Prendergast (2009) names it "a calling between the 'I' and the 'Other' (p.xxxv). Hasebe-Ludt, Chambers and Leggo (2009) expand:"We learn to practice this generosity of spirit in relation to ourselves and others, acknowledging how we are all inextricably and ecologically connected, all of us needing to be heard" (p. 154).

\section{Break the Glass²}

Last night I dreamt
of marrying my
long time lover
in a ceremony out
in the frozen pasture
beneath the halo of a
brimming January moon
before us a crystalline field
cocooned guests exhaling joy
everyone dancing and
breathing in persimmon light
the chupah held up by
larch and lombardi poplar
fir and maple

steady limbs

for a crowd of ravens

their beaks open in awe

I promise to live here amongst the slugs and swallows stinging nettles and california quail

pinch me

here I will thrive

till death do us part

tending our hillside orchard singing songs of pear and apple cherry and fig

go ahead wind, break the glass 


\section{Seasons of Relationship}

Meaning sprouts in the very depths of the sensory world, in the heat of meeting, encounter, participation.

(Abram, 1996, p. 75)

As I walk through the gates of the farm at each season, I am exposed to each season's interpretation of sun and soil, wind and water. Daily I encounter birth, death and a full range of experience in between. Thus I learn patience, to wait the seasons out. I engage with the bitter months of winter knowing that surly spring will surely come when it is time. Walking steadily, I

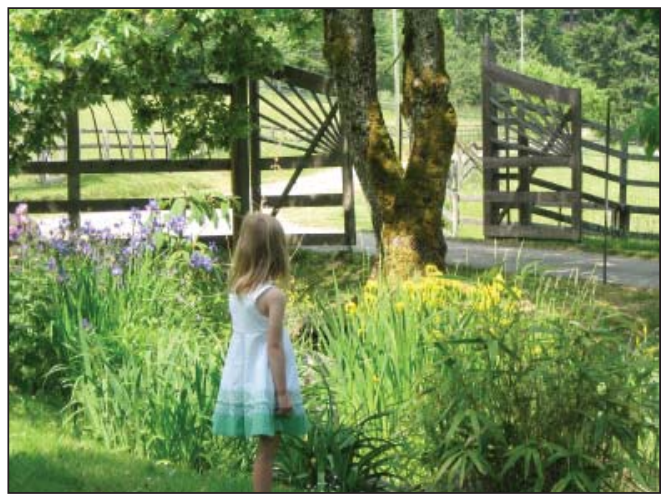

Fig. 4: Sprung learn to see and appreciate the beauty of each season.

Ode to Woodpecker After Pablo Neruda

1.

Busy bird

I cannot decipher

your sounds

as your beak breaks

through rotting wood

beside you, lombardi poplar

rustles and shakes

accompanies your pecking

other birds follow

from the garden robins poke choke cherry tree

yellow jackets wheedle

snapdragon's royal reds

pounding from the

farm next door

a shot

yet stillness

reigns 
2.

Construction on the farm

Tyrannosaurus Ex-

cavator rips trees

devours your nests, ants

fledglings
3.

Being human is a misery

given power to destroy

we erect new buildings

to create again

oh woodpecker

you shred rectangles

dig out food

other creatures depend

on your labours

like men who wield

the saw and back hoe

so that families may live

more comfortably

What if we stopped assuming that to be powerful means to require worship and obedience? What if we imagined that it might mean the ability to participate in pain and joy?

(Ostriker, 2000, p. 15)

\section{Passover}

It is Passover and as a Jew

I am called to remember

that once we were slaves

in Egypt, and Moses saved us

(aided by his sister Miriam,

\& brother Aaron) 
who led us 40 years through the desert, brought us to a land of milk and honey.

I wonder how my grandparents' parents celebrated

in the shtet/s of Romania and Poland,

what songs they sang at the seder table

who was chosen to ask the Four Questions.

All this I will never know

because Hitler invaded, led my

family into gas chambers, went through

their personal objects, sorted their gold

rings and glasses.

This morning I contemplate different questions:

In what language did they sing?

Did any of my great great aunts write poetry?

Who opened the door for Eliahu?

What kind of jam did they eat on their matzoh?

As I practice Loving Inquiry on the farm, I also enter into the heart's expansive repertoire of feeling. As the gates open and close, as the breath moves in and out, so my heart knows sorrow and joy, pain and pleasure. I learn to recognize the seasons of relationship, to honour the constant shifts and changes, and to have compassion for the journey we all must take through the gates of our own hearts.

\section{What the Heart Leaves Behind}

Sun slaps your cheek like a heavy rain, forces you to turn, look another way 
A thin coat hangs off your shoulders, wind picks

it up,

sails it across the yard.

You see through a periscope of weather.

Fortunately dinner is already planned:

broiled fish in lemon juice and olive oil, baked baby beets \& new potatoes, fresh mint and chives from the garden.

About ten minutes ago you were in bed with your lover, flannel housecoat wrapped around you.

Now scents of purple italian plums and basil mingle with August coolness.

Contemplate change.

It can happen so quietly, without billboards or pendulums.

It happens so quietly,

the night sweats,

thickening around your hips,

breasts befriend waist, become accustomed

to meeting halfway.

Belly juts out awkwardly.

You resent its forthrightness, have always preferred mellow, reserved.

Local creatures comfort, inspire.

Their songs wobbly, undelicate.

Your body temperature rises with the moon.

As do your prospects for better pay, shorter hours.

Someone finally recognizes your wisdom, understands your humour. 
It is all about a house on a hill in a valley,

all about a man and a woman, several, a pasture, orchards, a handful of ponds.

How can it be all about anything?

Everything buzzes.

The refrigerator, morning chickadees, your purple vibrator.

Sounds you

have come to trust, rely on.

Fire all your ex-bosses

Climb down their ladders

Find sturdy flagstone paths that snake past

$$
\begin{gathered}
\text { lilac } \\
\text { roses } \\
\text { clematis } \\
\text { honeysuckle } \\
\text { lupine. }
\end{gathered}
$$

Their names mean something.

This morning you open a new gate,

the last one almost closed behind you,

a remaining sliver of green

where the wood splinters at the clasp.

It's out of your control.

This new one

creaks when you push your hand against it,

reminds you of screen doors on camping trailers with family in Swanton Vermont.

It is a good sign.

Nothing moves forward without taking some of the past with it. 


\section{Reframing Connection}

In entering the domain of the heart, I yearn for a language.

(Denton, 1998, p. 33)

Walking through the gates I engage in artistic and contemplative practices in order to keep opening my heart into fresh and fruitful understandings of my experience of relationship. Poet and educator Carl Leggo (2004) asserts: "[P]oetry invites me to breathe, to attend, to slow down, to embrace the healing of body and spirit and imagination" (para 1). By employing poetry, I seek to

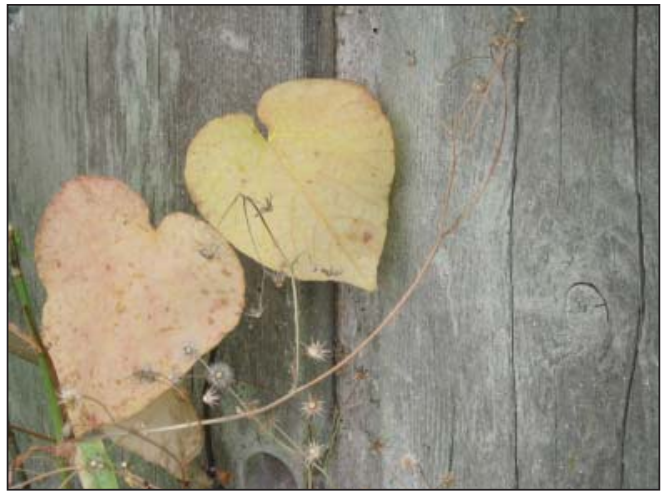

Fig. 5: Listen promote a diversity of stories and meanings within these relationships.

Through sharing this nuanced practice of engagement in relationship between self and other in the particular context of Butterstone Farm, on Salt Spring Island, I seek to open up connections with researchers and scholars who are similarly and diversely located within and among the field(s) of education including spirituality, ecology, arts-based practice, violence prevention/healthy relationships and social justice education.

\section{Reinterpret}

You want to tell everything that happens each day on the farm

this poem has other plans

what you have to say is not irrelevant

it is giving up one world for innumerable others 
this is your

the birds and

your disappearance

the empty vase

each season's blossoming

self-forgetful

as if your next breath

were

as if you belong to

as if the world hinges on the slant

of your right hand

here

as if there never was a better moment to

and you explain it to us

what it means to feel this

then you hear something

scatter yourself

reinterpret

It can be very awkward to move from between seeing with the eye of judgment and the eye of the heart, half caught in an old way of being and yet sensing, even remembering, that a larger and more generous vision is possible.

(Gendler, 2007, p. 109)

This work develops the conversation on how we may engage in loving relationships with ourselves and others within and beyond the scope of our human relationships. It expands this pedagogical practice from the walls of schools and universities out toward our experience with nature. I write of my particular location and 
situation with the desire to inspire and educate others to attend to their relationships within their particular personal, political and pedagogical locations. As Hasebe-Ludt et al. (2009) assert: "To write is a political act. To write in the particular is deeply political" (pp. 86-87).

Through the Gates of Loving Inquiry communicates a transformative vision of loving relationship as a passionate practice of ongoing attention to the generative possibilities available within our moment to moment experiences of being in the world. There is always another gate to open, another opportunity for the heart to move into relationship.

\section{Notes}

1. This article is based on the research from my doctoral dissertation, Through the Gates of Loving Inquiry: Where the Heart Opens into Relationship (UBC, 2010). Some of the text and images in the article also appear in The Art of Poetic Inquiry (Backalong Books).

2. In the Jewish tradition, the groom breaks a glass at the end of the marriage ceremony, symbolizing the destruction of the Second Temple in the second century BCE. As the couple celebrates the joy of their new beginning, they are also asked to remember the adversity of the Jewish people.

\section{References}

Abram, D. (1996). The spell of the sensuous: Perception and language in a more than human world. New York: Vintage Books.

Arrien, A. (2005). The second half of life: Opening the eight gates of wisdom. Boulder: Sounds True, Inc.

Ayers, W. (2004). Headaches: On teaching and teacher education. In Teaching the personal and the political: Essays on hope and justice (pp. 102-112). New York: Teachers College Press.
Boorstein, S. (2002). Pay attention, for goodness' sake: Practicing the Buddhist path of kindness. New York: Ballantine Books.

Bringhurst, R. (1995). Everywhere being is dancing, knowing is known. In Poetry and knowing: Speculative essays \& interviews, T. Lilburn (Ed). Kingston, Ontario: Quarry Press. (pp. 52-64)

Chodron, P. (2002). Comfortable with uncertainty: 108 teachings. Boston: Shambhala. 
Denton, D. (1998). In the tenderness of stone: Liberating consciousness through the awakening of the heart. Pittsburgh: Sterling House Publisher.

Fels, L., \& Meyer, K. (in press). Angel words within prison gates: Participatory action research as action towards restorative justice. In International Perspectives on Restorative Justice in Education, J. Charlton, PJ Verrecchia, \& D. Polizzi, (Eds.). Ontario, Canada: Centre for the Study of Crime, Restorative Justice and Community Safety.

Gendler, J.R. (2007). Notes on the need for beauty: An intimate look at an essential quality. New York: Marlowe \& Company.

Harding, S. (2006). Animate earth: Science, intuition and gaia. Devon: Green Books.

Hasebe-Ludt, E., Chambers, C. M., \& Leggo, C. (2009). Life writing and literary métissage as an ethos for our times. New York: Peter Lang.

Hirshfield, J. (1997). Nine gates: Entering the mind of poetry. New York: Harper Collins.

Irigaray, L. (2002). The way of love. London: Continuum.

Lauterbach, A. (2005). The night sky: Writings on the poetics of experience. New York: Penguin Books.

Leggo, C. (2004). The curriculum of joy: Six poetic ruminations. Journal of the Canadian Association for Curriculum Studies, 2(2), 27-42.

Loori, J. D. (1992). The eight gates of Zen: Spiritual training in an American Zen monastery. Mt. Tremper, NY: Dharma Communications.

Merton, T. (2008). Choosing to love the world: On contemplation. J. Montaldo (Ed.). Boulder: Sounds True, Inc.
Meyer, K. (2006). Living Inquiry: A Gateless Gate and a Beach. In W. Ashton \& D. Denton (Eds.), Spirituality, Ethnography, and Teaching, Stories from Within (pp. 155-166). New York: Peter Lang.

Momaday, S. (1993). The way to rainy mountain. Albuquerque: University of New Mexico Press.

Ostriker, A.S. (2000). Dancing at the devil's party: Essays on poetry, politics, and the erotic. Ann Arbor: University of Michigan Press.

Palmer, P. J. (1983). To know as we are known: Education as a spiritual journey. San Francisco: Harper San Francisco.

Prendergast, M. (Ed.). (2009). Poetic inquiry: Vibrant voices in the academy (pp. xix-xxxvii). Rotterdam: Sense Publishers.

Shibayama, Z. (2000). The gateless barrier: Zen comments on the mumonkan. Boston: Shambhala.

Shira, A. (1998). Womb: Weaving of my being. Vancouver: Butterfly Press.

Shira, A. (2005). Tahiti. Arts-Informed: The Journal of the Centre for Arts-Informed Research, 4(2 \& 3).

Shira, A. (2007). Inside swova's respectful relationships program. Canadian Women's Foundation newsletter, June.

Shira, A. (2008). i.e. Educational Insights, 12(1).

Shira, A. (2009). Writing the number 4 bus: A poetic inquiry. Educational Insights, 13(3).

Whyte, D. (1997). The house of belonging. Langley: Many Rivers Press.

Yamada, K. (2004). Gateless gate: The classic book of zen koans. Somerville: Wisdom Publications. 


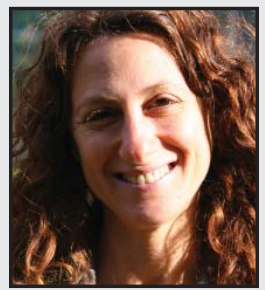

Ahava Shira holds a PhD from the Department of Language \& Literacy Education at the University of British Columbia. Her poetry and essays are published in the journals Educational Insights and Arts-Informed. She is also the author of a book of poetry, Womb: Weaving of My Being (1998), and a poetry CD, Love is Like This (2010). Ahava is the founder and educational director of the Centre for Loving Inquiry, offering online courses, trainings and retreats for educators \& professionals interested in developing their skills in the creative \& contemplative arts.

\section{LINKTO:}

www.ahavashira.com

https://circle.ubc.ca/handle/2429/23330 